\title{
PERKEMBANGAN PENERAPAN PRINSIP PIERCING THE CORPORATE VEIL DALAM PELANGGARAN FIDUCIARY DUTY YANG DILAKUKAN DIREKSI PERSEROAN TERBATAS
}

\author{
Sandra Dewi \\ Program Studi Doktor Ilmu Hukum \\ Pascasarjana Universitas Islam Bandung \\ e-mail: sandradw1998@gmail.com
}

\begin{abstract}
Abstrak- Studi ini menganalisis perkembangan penerapan prinsip Piercing the Corporate Veil dari sebuah perusahaan terhadap pelanggaran kewajiban fidusia yang dilakukan oleh direksi perseroan terbatas. Penelitian ini menggunakan metode yuridis normatif dengan menggunakan studi kepustakaan untuk memperoleh data sekunder termasuk bahan hukum primer, sekunder dan tersier. Penelitian ini menyimpulkan bahwa direksi perusahaan adalah organ perusahaan yang bertanggung jawab atas operasional perusahaan. Mereka harus menjalankan kewajiban dengan itikad baik dan bertanggung jawab penuh. Para direksi juga memegang kewajiban fidusia perusahaan. Jika direksi gagal melaksanakan kewajibannya, mereka tunduk pada prinsip Piercing the Corporate Veil dan secara pribadi bertanggung jawab atas kerugian yang diderita oleh perusahaan, pemegang saham, atau pemangku kepentingan.
\end{abstract}

Kata kunci: Piercing the Corporate Veil, Direksi perseroan terbatas.

\begin{abstract}
This study analyzes the development of piercing the corporate veil principle application of a company towards violations of fiduciary obligations committed by directors of limited company. This study uses normative juridical method utilizing library research to obtain secondary data including primary, secondary and tertiary of legal materials. This study concluded that the company's directors is the organ of company who responsible for the operational of the company. They should carry out the obligations in good faith and fully responsible. The directors also hold fiduciary obligations of the company. If the directors failed to perform their obligations, they are subject to the principle of Piercing the Corporate Veil and personally responsible for the losses suffered by the company, shareholders, or stakeholder.
\end{abstract}

Keywords: Piercing the Corporate Veil, Fiduciary Company Directors.

\section{A. PENDAHULUAN}

Perseroan Terbatas (selanjutnya disebut PT) merupakan suatu bentuk usaha yang paling banyak diminati di Indonesia. Hal ini dikarenakan perseroan terbatas merupakan suatu bentuk usaha dan badan hukum yang mandiri. Pengertian PT berdasarkan Pasal 1 butir 1 Undang-Undang Nomor 40 Tahun 2007 tentang Perseroan Terbatas (selanjutnya 
disebut UUPT) yang dimaksud dengan PT yaitu:

"Badan hukum yang merupakan persekutuan modal, didirikan berdasarkan perjanjian, melakukan kegiatan usaha dengan modal dasar yang seluruhnya terbagi dalam saham dan memenuhi persyaratan yang ditetapkan dalam undangundang ini serta peraturan pelaksanaannya".

PT merupakan badan usaha yang besar modalnya tercantum dalam anggaran dasar, selain itu tanggung jawab para pemegang saham bersifat terbatas hanya tergantung pada besar saham yang dimiliki dalam perseroan. Tanggung jawab pemegang saham secara terbatas ini merupakan tirai atau benteng yang memisahkan tanggung jawab pemegang saham dengan tanggung jawab pengurus dalam menjalankan kegiatan usaha perseroan. Akan tetapi tirai tersebut bukan bersifat mutlak dan tidak dapat ditembus. Didasarkan pada rasa kekhawatiran bahwa penerapan prinsip pembatasan tanggungjawab bertendensi akan membawa ketidakadilan, muncul doktrin atau prinsip yang disebut Piercing the Corporate Veil. Secara harfiah, istilah
Piercing the Corporate Veil berarti membuka tirai perseroan, dimana kekebalan yang biasa dimiliki oleh pemegang saham, direksi dan komisaris, yaitu tanggung jawabnya terbatas dibuka dan diterobos menjadi tanggung jawab tidak terbatas, hingga kekayaan pribadi manakala terjadi pelanggaran, penyimpangan atsu kesalahan dalam menjalankan operasional perseroan (Chatamarrasjid Ais, 2000:12).

Prinsip Piercing the Corporate Veil tersebut diatur dalam Pasal 3 ayat (2) UUPT mengatur, tanggung jawab terbatas dari pemegang saham tidak berlaku atau hapus jika: persyaratan perseroan sebagai badan hukum belum atau tidak terpenuhi, yaitu dalam hal ini belum disahkannya Akta Pendirian perseroan oleh Menteri Hukum dan HAM dan status perseroan disini belum menjadi badan hukum; pemegang saham yang bersangkutan baik langsung maupun tidak langsung dengan itikad buruk memanfaatkan perseroan semata-mata untuk kepentingan pribadi, seperti misalnya terbukti bahwa terjadi pembauran harta kekayaan pribadi pemegang saham dan harta kekayaan 
perseroan, sehingga perseroan didirikan semata-mata sebagai alat yang dipergunakan pemegang saham untuk memenuhi tujuan pribadinya; pemegang saham yang bersangkutan terlibat dalam perbuatan melawan hukum yang dilakukan oleh perseroan; atau pemegang saham yang bersangkutan baik langsung maupun tidak langsung secara melawan hukum menggunakan kekayaan perseroan, yang mengakibatkan kekayaan perseroan menjadi tidak cukup untuk melunasi utang perseroan (Nindyo Pramono, 2001:32).

Dalam PT selain kekayaan perusahaan dan kekayaan pemilik modal terpisah juga ada pemisahan antara pemilik perusahaan dan pengelola perseroan. Pengelolaan perseroan dapat diserahkan kepada tenaga-tenaga ahli dalam bidangnya (profesional). Komponen atau organorgan perseroan terbatas terdiri dari pemegang saham, direksi, dan komisaris. Untuk itu dibutuhkan kerangka kerja hukum yang pasti agar unit usaha ini dapat bekerja dengan produktif dan efisien, dan tedapat arahan hukum yang jelas bagi PT dalam melaksanakan kegiatannya.

Dalam sebuah PT, direksi merupakan motor penggerak perseroan, mengingat direksi adalah organ perseroan yang bertanggungjawab atas seluruh kegiatan perseroan. Hubungan antara direksi dengan perseroan adalah hubungan saling ketergantungan, satu dengan yang lain saling tergantung, sebagai organ yang dipercayakan untuk melakukan pengurusan perseroan. Perseroan merupakan sebab adanya direksi. Tanpa perseroan maka direksi tidak pernah ada. Begitu juga direksi, tanpa direksi maka perseroan tidak dapat berjalan sebagaimana mestinya.

Berdasarkan uraian tersebut di atas maka dapat dikatakan organ perseroan yang memegang posisi sangat penting adalah direksi. Pasal 1 angka 5 UUPT menyebutkan bahwa direksi suatu perseroan berwenang dan bertanggungjawab penuh atas pengurusan perseroan untuk kepentingan perseroan, sesuai dengan maksud dan tujuan perseroan serta mewakili perseroan, baik di dalam maupun di luar pengadilan sesuai 
dengan ketentuan anggaran dasar. perundang-undangan dan Anggaran Maju dan berkembangnya perseroan Dasar dan Anggaran Rumah Tangga ditentukan oleh direksi. Direksi menjadikan perseroan hidup, tanpa (ADRT) suatu PT. Direksi yang menjalankan kepengurusan perseroan direksi perseroan tidak dapat di dalam garis yang telah ditentukan, menjalankan kewajibannya. Segala hal yang berhubungan dengan tidak dapat dimintai kegiatan perseroan dijalankan oleh direksi.

Tugas direksi didasarkan pada doktrin fiduciary duty. Doktrin fiduciary duty berasal dari sistem hukum Common Law yang mengajarkan bahwa antar direksi dengan perseroan terdapat hubungan fiduciary. Direksi hanya bertindak seperti sprang trustee atau agen semata-mata, yang mempunyai kewajiban mengabdi sepenuhnya dan dengan sebaik-baiknya kepada perseroan (Marwan, 2009:207). Direksi dituntut harus dapat mempunyai kepedulian dan kemampuan (duty of care and skill), itikad baik, loyalitas, dan kejujuran terhadap perusahaannya dengan derajat yang tinggi (high degree) (Munir Fuady, 2010:47).

Kepercayaan yang diberikan
oleh perseroan tersebut harus
dijalankan sesuai dengan peraturan
pertanggungjawaban (Pasal 97 ayat (5) UUPT). Hal ini berakibat direksi tidak dapat dimintai pertanggungjawaban atas kerugian yang diderita oleh pihak perseroan atau pihak ketiga. Ketentuan ini berlaku untuk direksi yang mengelola perseroan dengan itikad baik saja. Apabila direksi terbukti menyalahgunakan wewenang untuk kepentingan pribadi atau golongan yang mengakibatkan perseroan ataupun pihak ketiga mengalami kerugian, maka direksi dapat dimintai tanggung jawab atas kerugian tersebut, bahkan sampai kepada harta pribadinya. Kondisi inilah yang menginspirasi penulis untuk menulis artikel dalam bentuk jurnal mengenai perkembangan penerapan prinsip Piercing the Corporate Veil dalam pelanggaran Fiduciary Duty yang dilakukan direksi Perseroan Terbatas.

Berdasarkan latar belakang yang dikemukakan di atas, maka 
dirumuskan permasalahan yaitu Bagaimana perkembangan penerapan prinsip Piercing the Corporate Veil dalam pelanggaran Fiduciary Duty yang dilakukan direksi Perseroan Terbatas?

\section{B. HASIL DAN PEMBAHASAN}

PT memiliki bentuk usaha mandiri (legal entity) dengan tangung jawab terbatas (limited liability). Kehendak dan kemauan yang dikehendaki perseroan dijalankan oleh alat-alat perlengkapannya atau organnya. Organ-organ tersebut mempunyai kewenangan dan tanggung jawab masing-masing sesuai yang telah diatur dalam peraturan perundang-undangan dan ADRT PT. Organ perseroan bertugas mewakili perseroan untuk dan atas nama perseroan.

\section{Pasal 1655 KUHPerdata} menyebutkan bahwa para pengurus badan hukum, bila tidak ditentukan lain dalam akta pendiriannya, dalam surat perjanjian, atau dalam reglemen, berkuasa untuk bertindak demi dan atas nama badan hukum itu, untuk mengikatkan badan hukum itu kepada pihak ketiga atau sebaliknya, dan untuk bertindak dalam sidang di pengadilan baik sebagai penggugat maupun sebagai tergugat. Badan hukum dalam hal ini adalah perseroan, dapat melakukan perbuatan hukum maupun hubungan hukum melalui organ pengurusnya yaitu organ-organ perseroan. Organorgan perseroan bertugas mewakili perseroan sesuai dengan apa yang telah ditentukan dalam ADRT PT, dalam surat perjanjian dan dalam peraturan perundang-undangan. Masing-masing organ mempunyai tugas dan wewenang tersendiri sesuai aturan yang berlaku dalam perseroan tersebut.

Rapat Umum Pemegang Sahan (RUPS) adalah forum bagi pemegang saham memperoleh keterangan yang berkaitan dengan perseroan dari direksi dan/atau dewan komisaris, sepanjang berhubungan dengan mata acara rapat dan tidak bertentangan dengan kepentingan perseroan (Jono, 2008:55). Direksi merupakan penerima kuasa dari perseroan sesuai dengan kepentingannya untuk mencapai tujuan perseroan sebagaimana telah digariskan dalam ADRT PT, sehingga tidak 
diperkenankan melakukan sesuatu yang tidak atau bukan menjadi tugasnya (Ahmad Yani, 1999:97).

Setiap tugas dan tanggung jawab direksi dalam menjalankan perseroan harus tunduk kepada ketentuan atau peraturan yang mengatur mengenai perseroan sesuai dengan maksud dan tujuan didirikannya perseroan tersebut (Pasal 1 angka 5 UUPT). Direksi dalam menjalankan pengurusan perseroan hanya untuk kepentingan perseroan dan sesuai dengan maksud dan tujuan perseroan sebagaimana yang diatur dalam Pasal 92 UUPT. Pada Pasal 2 UUPT ditegaskan bahwa kegiatan perseroan harus sesuai dengan maksud dan tujuannya serta tidak bertentangan dengan peraturan perundang-undangan, ketertiban umum, dan atau kesusilaan. Selanjutnya, pada Pasal 18 UUPT ditentukan bahwa maksud dan tujuan tersebut harus dicantumkan dalam ADRT PT sesuai dengan ketentuan undang-undang. Penjelasan pada Pasal 18 UUPT disebutkan bahwa maksud dan tujuan tersebut merupakan usaha pokok perseroan, sedangkan kegiatan usaha merupakan kegiatan yang dijalankan oleh perseroan dalam rangka mencapai maksud dan tujuannya yang harus dirinci secara jelas dalam anggaran dasar, dan tidak boleh bertentangan dengannya. Perseroan tidak diperkenankan melakukan kegiatan yang tidak sejalan dengan maksud dan tujuan perseroan.

Direksi diberi dua fungsi dalam mengemban tugasnya, yaitu fungsi pengurusan (manajemen) dan fungsi perwakilan (representasi) (Ridwan Khairandy, 2009:204). Fungsi pengurusan seorang direksi dilakukan ketika direksi mengemban tugasnya sebagai seorang yang mengurus kegiatan perseroan sehari-hari. Fungsi perwakilan adalah tugas direksi mewakili perseroan baik di dalam maupun di luar pengadilan. Begitu besar dan luas kewenangan seorang direksi perseroan. Tugas yang diemban oleh direksi ini harus dijaga dan dilaksanakan sebaik-baiknya. Kewenangan yang diperoleh direksi dari para pemegang saham (shareholder) didasarkan atas dasar kepercayaan (fiduciary) untuk mengurus perseroan demi kepentingan perseroan, bukan demi 
kepentingan pemegang saham atau pihak tertentu. Fidusia (fiduciary) dalam bahasa latin dikenal sebagai fiduciarius yang bermakna kepercayaan. Secara teknis dapat dimaknai sebagai memegang suatu dalam kepercayaan untuk kepentingan orang (Ridwan Khairandy, 2009:204).

Direksi wajib beritikad baik (good faith) dan penuh tanggung jawab dalam setiap melakukan pengurusan perseroan. Hal itu dilakukan berdasarkan suatu standar dari kewajiban (standard of duty) yang paling tinggi sesuai dengan yang dinyatakan oleh hukum. Seseorang yang memegang peran sebagai suatu wakil (trustee) atau suatu peran yang disamakan dengan sesuatu yang berperan sebagai wakil, dalam hal ini peran tersebut didasarkan kepercayaan dan kerahasiaan (trust and confidence) yang dalam peran ini meliputi, ketelitian (scrupulous), itikad baik (good faith), dan keterusterangan (candor). Fiduciary ini termasuk hubungan seperti pengurus atau pengelola, pengawas, wakil atau wali, dan pelindung (guardian) yang sering disebut dengan duty (Bismar Nasution, 2008).

Hubungan antara direksi dan perseroan tidak semata-mata hanya hubungan pekerjaan saja tetapi juga hubungan fidusia (fiducia position). Perseroan tidak dapat bertindak sendiri dan sangat tergantung kepada pengurusannya. Ketergantungan ini mengharuskan perseroan untuk mempercayai pengurus yang kemudian melahirkan hubungan fidusia dan lebih dikenal dengan fiduciary duty. Pengurus harus menjalankan kepengurusan dan kewenangannya semata-mata hanya untuk kepentingan perseroan. Fiduciary duty adalah tugas yang dijalankan oleh direksi dengan penuh tanggung jawab untuk kepentingan (benefit) orang atau pihak lain (perseroan) (Ridwan Khairandy, 2009:210). Apabila terjadi masalah manakala suatu perseroan beroperasi tidak layak sehingga menimbulkan kerugian pihak ketiga atau pemegang saham, dalam hal ini direksi bertanggung jawab sebagai pihak eksekutif berdasarkan doktrin fiduciary duty (Munir Fuady, 2010:25). 
Pada Pasal 97 ayat (2) dan (3) UUPT ditentukan bahwa kepengurusan yang dipercayakan kepada direksi harus dilaksanakan dengan itikad baik dan penuh tanggung jawab penuh sampai kepada harta pribadi direksi apabila direksi terbukti lalai dalam menjalankan tugasnya (Sutan Remi Syahdeni, 2001). Fiduciary duty yang telah diberikan kepada direksi suatu perseroan menuntutnya untuk memiliki standar integritas dan loyalitas yang tinggi, terampil, serta bertindak untuk kepentingan perseroan secara bona fides (Ridwan Khairandy, 2009:208). Pada Pasal 97 ayat (6) UUPT ditentukan bahwa apabila anggota direksi yang bersangkutan bersalah atau lalai melaksanakan tugasnya dengan baik sehingga perseroan dirugikan, maka ia bertanggung jawab penuh secara pribadi dan pemegang saham dapat mengajukan gugatan ke pengadilan negeri. Fiduciary duty dijalankan oleh direksi dengan cara (Ridwan

Khairandy, 2009:209), yaitu:

1. Dilakukan dengan itikad baik (bona fides);

2. Dilakukan dengan proper purpose;
3. Dilakukan dengan kebebasan yang bertanggung jawab (unfetiered discretion); dan

4. Tidak memiliki benturan kepentingan (conflict of duty and interest).

Tanggung jawab direksi tidak hanya terbatas pada ketidakjujuran yang disengaja tetapi juga tanggung jawab dalam tindakan mismanagement, kelalaian, kegagalan atau tidak melakukan sesuatu yang penting bagi perseroan. Itikad baik direksi dapat dilihat ketika direksi benar-benar mementingkan kepentingan perseroan, shareholder, dan stakeholder. Proper purpose (tujuan yang benar) dijalankan dengan menaati ADRT PT dan peraturan perundang-undangan. Menurut

M. Yahya Harahap, ada beberapa aspek pengurusan yang wajib dilakukan dengan itikad baik, (M. Yahya Harahap, 2009:383) yaitu:

1. Wajib dipercaya (fiduciary duty), yakni selama dapat dipercaya (must always bonafide) dan selamanya harus jujur (must always honest);

2. Wajib melaksananakan pengurusan untuk tujuan yang wajar atau layak (duty to act for proper purpose); 
3. Wajib menaati peraturan perundang-undangan (statutory duty or duty obedience);

4. Wajib loyal terhadap perseroan (loyalty duty), tidak menggunkan dana dan asset perseroan untuk kepentingan pribadi, wajib merahasiakan segala informasi (confidential duty of information) perseroan; dan

5. Wajib menghindari kepentingan pribadi dengan kepentingan perseroan (must avoid conflict of interest).

Direksi wajib melaksanakan pengurusan dengan penuh tangung jawab, (M. Yahya Harahap,

2009:383) yang meliputi aspek:

1. Wajib seksama dan hati-hati melakukan pengurusan (the duty of the due care), yakni kehati-hatian yang biasa dilakukan orang (ordinary prudent person) dalam kondisi yang wajar atau disebut dengan kehati-hatian yang wajar (reasonably care);

2. Wajib melaksanakan pengurusan secara tekun (duty to be diligent), yakni terus menerus secara wajar menumpahkan perhatian atas kejadian yang menimpa perseroan; dan

3. Ketekunan dan keuletan wajib disertai kecakapan dan keahlian (duty to display skill) sesuai dengan ilmu pengetahuan dan pengetahuan yang dimilikinya.

Seorang direksi tidak dapat dimintai pertanggungjawaban secara pribadi atas tindakan yang telah dilakukannya dalam kedudukannya sebagai direksi, apabila ia meyakini bahwa tindakan tersebut merupakan tindakan yang terbaik bagi perseroan dan dilakukan secara jujur, beritikad baik, dan tidak bertentangan dengan hukum yang berlaku. Direksi tidak akan dimintai pertanggungjawaban walaupun salah dalam mengambil keputusan (mere errors of judgement) ketika direksi beritikad baik dan penuh kehati-hatian dalam menjalankan tugasnya. Hal ini akan membantu direksi karena hakim tidak diperbolehkan melakukan penilaian bisnis yang berbentuk second guess terhadap keputusan bisnis yang diambil oleh direksi sesuai dengan teori keputusan bisnis (business judgement rule) (Munir Fuady, 2010:48). Setiap keputusan direksi yang diambil dilindungi oleh business judgement rule, namun direksi tetap harus beritikad baik, berhati-hati, dan penuh loyalitas dalam menjalankan kepengurusan perseroan.

Pada Pasal 97 ayat (2) UUPT diwajibkan setiap anggota direksi untuk beritikad baik dan penuh tangggung jawab dalam melaksanakan setiap tugas. Pasal inilah yang memberikan dasar 
pemberlakuan fiduciary duty oleh direksi di Indonesia. Fiduciary duty ini berlaku bagi kepentingan perseroan. Direksi berkewajiban untuk mengelola dan mengurus kepentingan perseroan secara keseluruhan bukan kepentingan pemegang saham baik secara individu maupun kelompok ataupun pihak ketiga. Hal ini sesuai dengan posisi seorang direksi sebagai sebuah trustee dalam perusahaan. Pelanggaran terhadap prinsip tersebut menyebabkan direksi untuk dimintai pertanggungjawaban hukumnya secara pribadi terhadap perbuatan yang dilakukannya baik kepada para pemegang saham maupun kepada pihak lainnya.

Apabila direksi dengan sengaja berbuat melampaui kewenangannya, maka dapat dikenakan ultra vires. Direksi yang dengan sengaja melanggar batas kewenangan tersebut dapat disebut telah melakukan tindakan ultra vires. Setiap tindakan ultra vires batal demi hukum karena tidak mempunyai landasan yuridis. Tindakan direksi tersebut tidak mempunyai kewenangan baik dari ADRT PT ataupun peraturan perundang-undangan yang berlaku. Tuntutan keadilan menyebabkan beberapa perbuatan yang digolongkan dalam ultra vires tidak dibatalkan, yaitu:

1. Restitusi (pengembalian) aset yang sudah dialihkan dengan transaksi yang ultra vires tidak mungkin dikembalikan lagi;

2. Perseroan telah diberi ganti rugi terhadap kerugian yang terjadi karena transaksi ultra vires tersebut;

3. Pembatalan transaksi akan merugikan hak yang didapat tidak secara gratis dari pihak ketiga yang beritikad baik di luar kontrak;

4. Transaksi yang mengandung ultra vires tersebut telah diratifikasi oleh RUPS atau oleh resolusi dari pemegang saham.

Akibat dari tidakan ultra vires adalah pihak yang dirugikan dapat meminta ganti rugi kepada direksi yang bersangkutan. Hal ini akan menjadi tanggung jawab tidak terbatas menjadi terkoyak karena kesalahan direksi. Apabila direksi terbukti melakukan kesalahan secara pribadi yang menyebabkan timbulnya kerugian bagi perseroan, maka direksi bertanggung jawab penuh secara pribadi untuk mengganti segala kerugian yang ditimbulkan terhadap perseroan. Direksi yang secara sengaja dengan itikad buruk 
Sandra Dewi, Perkembangan Penerapan Prinsip Piercing The Corporate Veil Dalam Pelanggara...

melakukan perbuatan melawan hukum dengan menggunakan harta kekayaan perseroan untuk kepentingan pribadinya sehingga menyebabkan timbulnya kerugian bagi perseroan dapat dijerat dengan Piercing the Corporate Veil. Piercing the Corporate Veil diberlakukan pada direksi apabila direksi terbukti melakukan kesalahan secara pribadi yang menyebabkan timbulnya kerugian perseroan. Tanggung jawab direksi berubah menjadi tanggung jawab tidak terbatas dan direksi bertanggung jawab penuh secara pribadi untuk mengganti segala kerugian yang ditimbulkan terhadap perseroan.

UUPT telah mengatur tanggungjawab pribadi direksi ini sejak UUPT Tahun 1995 dan UUPT Tahun 2007, sebagaimana dapat dilihat dalam tabel berikut ini: 


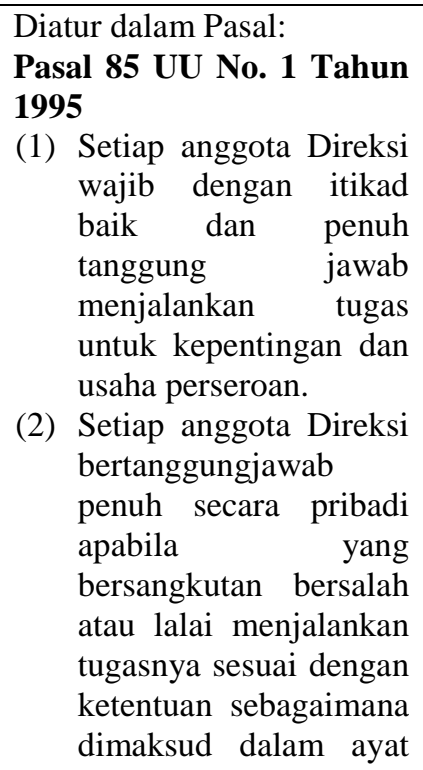

(1) Setiap anggota Direksi wajib dengan itikad baik dan penuh tanggung jawab menjalankan tugas untuk kepentingan dan usaha perseroan.

(2) Setiap anggota Direksi bertanggungjawab penuh secara pribadi apabila yang bersangkutan bersalah atau lalai menjalankan tugasnya sesuai dengan ketentuan sebagaimana dimaksud dalam ayat (1).

\section{Keterangan:}

Ketentuan di atas mengatur tanggung jawab pribadi dapat diberlakukan pada direksi

\section{Pasal 90 UU No. 1 Tahun} 1995

(2) Dalam hal kepailitan terjadi karena kesalahan atau kelalaian Direksi dan kekayaan perseroan tidak cukup untuk menutup kerugian akibat kepailitan tersebut, maka setiap anggota Direksi secara tanggung renteng bertanggung jawab atas kerugian itu.

\section{Keterangan:}

Ketentuan di atas mengatur mengenai tanggung jawab secara tanggung renteng (bertanggung jawab secara tanggung renteng bisa diartikan tanggung jawab pribadi)
Diatur dalam Pasal:

Pasal 69 UU No. 40 Tahun 2007

(3) Dalam hal laporan keuangan yang disediakan ternyata tidak benar dan/atau menyesatkan, anggota Direksi dan anggota Dewan Komisaris secara tanggung renteng bertanggung jawab terhadap pihak yang dirugikan.

\section{Keterangan:}

Ketentuan di atas mengatur tanggung jawab Direksi dan Komisaris secara tanggung renteng ((bertanggung jawab secara tanggung renteng bisa diartikan tanggung jawab pribadi)

Pasal 95 UU No. 40 Tahun 2007

(4) Perbuatan hukum yang dilakukan untuk dan atas nama Perseroan oleh anggota Direksi sebagaimana dimaksud pada ayat (1) setelah pengangkatannya batal, adalah tidak sah dan menjadi tanggung jawab pribadi anggota Direksi yang bersangkutan

\section{Keterangan:}

Ketentuan di atas mengatur tanggung jawab Direksi secara pribadi.

\section{Pasal 97 UU No. 40 Tahun 2007}

(3) Setiap anggota Direksi bertanggung jawab penuh secara pribadi atas kerugian Perseroan apabila yang bersangkutan bersalah atau lalai menjalankan tugasnya sesuai dengan ketentuan sebagaimana dimaksud pada ayat (2).

\section{Keterangan:}

Ketentuan di atas mengatur tanggung jawab Direksi secara pribadi.

\section{Pasal 101 UU No. 40 Tahun 2007}

(2) Anggota Direksi yang tidak melaksanakan kewajiban sebagaimana dimaksud pada ayat (1) dan menimbulkan kerugian bagi Perseroan, bertanggung jawab secara pribadi atas kerugian Perseroan tersebut.

\section{Keterangan:}

Ketentuan di atas mengatur tanggung jawab Direksi secara pribadi.

\section{Pasal 104 UU No. 40 Tahun 2007}

(2) Dalam hal kepailitan sebagaimana dimaksud pada ayat (1) terjadi karena kesalahan atau kelalaian Direksi dan harta pailit tidak cukup untuk membayar seluruh kewajiban Perseroan dalam kepailitan tersebut, setiap anggota Direksi secara tanggung renteng bertanggung jawab atas seluruh kewajiban yang tidak terlunasi dari harta pailit tersebut.

\section{Keterangan:}

Ketentuan di atas mengatur tanggung jawab Direksi secara pribadi.

Tabel di atas menunjukkan 
khusus, namun terdapat ketentuanketentuan yang berlaku bagi direksi yang dapat dianggap seperti prinsip Piercing the Corporate Veil yaitu dalam Pasal 85 dan Pasal 90 UU No.

1 Tahun 1995 mengatur tanggung jawab pribadi dari direksi perseroan, apabila direksi bersalah atau lalai dalam menjalankan tugasnya.

UUPT mengatur lebih lengkap mengenai penerapan prinsip Piercing the Corporate Veil atau tanggung jawab tidak terbatas atau tanggung jawab pribadi yaitu tanggung jawab pribadi direksi (diatur dalam Pasal 69 ayat (3) Pasal 95 ayat (4), Pasal 97 ayat (3), Pasal 101 ayat (2), Pasal 104 ayat (2) UUPT).

Berdasarkan uraian di atas maka dapat dikatakan bahwa dalam UU No. 1 Tahun 1995 dan UUPT, sudah diatur tanggung jawab tidak terbatas atau tanggung jawab pribadi yaitu tanggung jawab pribadi pemegang saham dan direksi yang diatur dalam UU No. 1 Tahun 1995 dan tanggung jawab pribadi pemegang saham, direksi dan komisaris yang diatur dalam UUPT.

Penerapan prinsip Piercing the Corporate Veil atau tanggung jawab tidak terbatas atau tanggung jawab pribadi, yang pada awalnya hanya berlaku untuk pemegang saham saja, dalam perkembangannya juga diberlakukan terhadap direksi dan komisaris sebagaimana diatur dalam UUPT seperti diterangkan di atas. Perkembangan penerapan prinsip Piercing the Corporate Veil ini seperti dikatakan oleh Jack P. Friedman (Jack P. Friedman, 1987:432) sebagai berikut:

"Process of imposing liability for corporate activity, in disregard of corporate activity, on a person or entity other that the offending corporate itself There are times when the court will ignore the corporate entity and strip they organizers and managers of the corporation of the limited liability that they usually enjoy. In doing so, the court is said to Piercing the Corporate Veil".

Dari pernyataan tersebut dapat dikatakan bahwa keberadaan prinsip Piercing the Corporate Veil penegak hukum akan mengabaikan status badan hukum dari perusahaan, dan membebankan tanggung jawab kepada pihak "organizers" dan "managers" dari perseroan dengan mengabaikan prinsip tanggung jawab terbatas dari perseroan sebagai badan 
hukum yang kerap dinikmati oleh mereka. Dalam melakukan hal tersebut biasanya dikatakan bahwa pengadilan telah mengoyak/ menyingkapi tirai/ kerudung perusahaan (to Pierce the Corporate Veil).

Hal yang sama juga dikatakan Munir Fuady yang menyatakan dalam pengembangannya prinsip Piercing the Corporate Veil tidak hanya berlaku untuk pemegang saham saja, namun juga membebankan tanggung jawab hukum kepada organ perusahaan lain, seperti direksi atau komisaris. Selanjutnya menurut Gunawan Widjaja, penerapan teori Piercing the Corporate Veil kedalam tindakan suatu perseroan menyebabkan tanggung jawab hukum tidak hanya dimintakan dari perseroan tersebut, tetapi juga pertanggungjawaban hukum dapat dimintakan terhadap pemegang sahamnya. Bahkan, penerapan teori Piercing the Corporate Veil juga membebankan tanggung jawab hukum kepada organ perusahaan yang lain, seperti direksi atau komisaris (Gunawan Widjaja, 2008:25-27).
Berdasarkan pernyataan tersebut, maka dapat dikatakan penerapan Piercing the Corporate Veil tidak hanya dapat dilakukan oleh pemegang saham perseroan, melainkan juga oleh setiap pihak yang dalam kedudukannya memungkinkan terjadinya penyimpangan atau dilakukannya halhal yang dapat, atau dilakukannya hal-hal yang sepatutnya dilakukan, yang bermuara pada terjadinya kerugian bagi perseroan, sehingga perseroan tidak dapat atau tidak sanggup lagi memenuhi seluruh kewajibannya (Gunawan Widjaja, 2008:27).

Piercing the Corporate Veil tidak dengan mudah diterapkan oleh pengadilan karena limited liability yang dimiliki perseroan amat kuat dan tidak tergoyahkan begiu saja. Penerapan prinsip Percing the Corporate Veil oleh pengadilan dilakukan dengan memperhatikan substansi atau kenyataan praktis pada bentuk formal dari perseroan tersebut (Chatamarrasjid Ais, 2004:14). Apabila terdapat kemungkinan perseroan disalahgunakan atau dijadikan selubung oleh pemegang 
saham atau direksi atau komisaris, maka pengadilan akan menyingkap tabir perseroan tersebut dan membuka maksud terselubung organ perseroan tersebut.

Sebagaimanana menurut Philiip Lepton, Pengadilan Australia secara umum tabu untuk membuka cadar perseroan tertabatas (Phillip and Lipton dan Abe Herzberg, 1993:31). Penerobosan cadar perseroan di Australia sangat jarang terjadi. Penulis buku Understanding Company Law menyebutkan beberapa alasan yang menyebabkan pengadilan di Australia menerobos cadar perseroan (Shinta Ikayani Kusumawardani， 2013:5) diantara adalah:

1. Where a company is used as vehicle for fraud;

2. If a company has been used so as to avoid a legal duty;

3. If the incorporation of a company can be seen to be a sham77 or the company is mere "puppet" of its controller;

4. If a company knowingly participates in a director's breach of her or his fiduciary duties.

Penerobosan tanggung jawab terbatas pada perseroan di Australia dapat dilakukan antara lain dalam hal perseroan dipergunakan sebagai alat untuk melakukan penipuaan, penghindaran suatu kewajiban hukum, sebagai topeng semata oleh pengendali, atau jika direksi melanggar kewajiban fiduciary (Shinta Ikayani Kusumawardani, 2013:5). Doktrin ultra vires dimaksudkan untuk melindungi para investor atau pemegang saham dari tindakan direksi yang merugikan perseroan. Tindakan ultra vires adalah tidak sah (unlawful) dan batal demi hukum sehingga RUPS tidak dapat mengesahkannya. Kontrak tersebut tidak mengikat perseroan dan perseroan tidak wajib melaksanakannya.

Direksi sebagai organ yang bertugas dan bertanggung jawab melaksanakan pengurusan perusahaan sangat berpotensi melakukan pelanggaran atau penyimpangan tugas dan kewajiban yang dibebankan kepada direksi. Direksi yang secara sengaja dengan itikad buruk melakukan perbuatan melawan hukum dengan menggunakan harta kekayaan perseroan untuk kepentingan pribadinya, sehingga menyebabkan timbulnya kerugian bagi perseroan, maka diterapkan asas 
Piercing the Corporate Veil yaitu pertanggungjawaban penuh secara pribadi untuk mengganti segala kerugian yang ditimbulkan terhadap perseroan jika direksi terbukti melakukan kesalahan secara pribadi yang menyebabkan timbulnya kerugian bagi perseroan. Pengadilan akan mengesampingkan status badan hukum perseroan tersebut dan membebankan tanggung jawab kepada direksi dengan mengabaikan prinsip tanggung jawab terbatas. Apabila direksi terbukti melakukan kesalahan secara pribadi yang menyebabkan timbulnya kerugian bagi perseroan, maka tidak ada lagi ruang bagi direksi sebagai pengurus perseroan untuk melakukan perbuatan yang dapat menimbulkan kerugian bagi perseroan, pemegang saham, ataupun pihak ketiga.

Pada tindakan direksi yang menyebabkan kerugian bagi perseroan dan berakhir kepada pailitnya perseroan, direksi wajib bertanggung jawab secara renteng atas kerugian tersebut (Gunawan Widjaja, 2004:145). Ini merupakan akibat dari kegagalan direksi yang dipercaya untuk mengurus perseroan.
Apabila kekayaan perseroan tidak cukup untuk menutup kewajiban perseroan, maka harta direksi yang bersangkutan akan digunakan untuk menutup kewajiban tersebut. Sifat pertanggungjawaban renteng dan pertanggungjawaban pribadi direksi menjadi sangat relevan dalam hal direksi melakukan penyimpangan atas kuasa dan perintah perseroan untuk kepentingan perseroan.

Hal itu secara tegas diakui Pasal 92 ayat (2) UUPT dan penjelasannya. Direksi berwenang menjalankan kepengurusan perseroan dengan menerapkan kebijakan yang dianggap tepat, yaitu kebijakan yang didasarkan pada keahlian, peluang yang tersedia, dan kelaziman dalam dunia usaha yang sejenis. Direksi harus selalu bertindak berdasarkan itikad baik dengan mengacu pada informasi yang cukup dan diolah secara cakap berdasarkan kemampuannya

(Wahyono

Darmabrata, 2003:30).

Apabila direksi terbukti melakukan kesalahan secara pribadi yang menyebabkan timbulnya kerugian bagi perseroan, maka tanggung jawab direksi berubah 
menjadi tanggung jawab tidak terbatas, sehingga direksi bertanggung jawab penuh secara pribadi untuk mengganti segala kerugian yang ditimbulkan terhadap perseroan. Pengadilan akan mengesampingkan status badan hukum dari perseroan tersebut dan membebankan tanggung jawab kepada direksi dengan mengabaikan prinsip tanggung jawab terbatas apabila direksi terbukti melakukan kesalahan secara pribadi yang menyebabkan timbulnya kerugian bagi perseroan. Hal tersebut membuat tidak ada lagi ruang bagi direksi sebagai pengurus perseroan untuk melakukan perbuatan yang dapat menimbulkan kerugian bagi perseroan.

Apabila di dalam pelaksanaan dan/atau berjalannya perseroan direksi melakukan kesalahan pelanggaran atas tugas-tugasnya, maka sebagaimana pada Pasal 97 ayat (2) dan (3) UUPT dapat dikenakan sanksi sebagai berikut:

“(2) Pengurusan sebagaimana dimaksud pada ayat (1), wajib dilaksanakan setiap anggota direksi dengan itikad baik dan penuh tanggung jawab; (3) Setiap anggota direksi bertanggung jawab penuh secara pribadi atas kerugian perseroan apabila yang bersangkutan bersalah atau lalai menjalankan tugasnya sesuai dengan ketentuan sebagaimana dimaksud pada ayat (2)."

Direksi bertanggung jawab secara renteng dalam pasal di atas berarti masingmasing anggota direksi memiliki tanggung jawab, dan pihak yang dirugikan dapat menuntut ganti rugi dari anggota direksi atas keseluruhan jumlah kerugian yang dideritanya (Sutan Remy Sjahdeini, http://wordpress.com). Kerugian perseroan yang disebabkan kelalaian direksi dalam menjalankan kewajiban atau melanggar larangan atas kepengurusan, direksi bertanggung jawab penuh secara pribadi (persoonlijk aansprakelijk, personally liable) (M. Yahya Harahap, 2009:384) atas kerugian tersebut.

Pada Pasal 97 UUPT diatur bahwa kepengurusan yang dipercayakan kepada direksi harus dilaksanakan dengan itikad baik dan penuh tanggung jawab. Apabila direksi terbukti salah atau lalai dalam menjalankan kepengurusannya (beritikad tidak baik) mengakibatkan perseroan rugi, pemegang saham 
yang mewakili minimal $1 / 10$ bagian dari jumlah seluruh saham dengan hak suara yang sah, (Jono, 2008:65) sesuai ketentuan yang ada berhak menggugat direksi bersangkutan untuk dimintai pertanggungjawaban secara penuh dengan mengajukan gugatan ke pengadilan negeri.

Direksi juga dapat dimintai pertanggungjawaban dalam hal perusahaan pailit apabila direksi terbukti memenuhi semua syarat (Jono, 2008:24) sebagai berikut:

1. Terdapat unsur kesalahan (kesengajaan) atau kelalaian dari direksi (dengan pembuktian biasa);

2. Untuk membayar utang dan ongkos-ongkos kepailitan, haruslah diambil terlebih dahulu dari aset-aset perseroan. Apabila aset perseroan tidak memenuhi barulah diambil dari aset direksi pribadi; dan

3. Diberlakukan pembuktian terbalik (omkering van bewijslast) bagi anggota direksi yang dapat membutikan bahwa kepailitan perseroan bukan karena kesalahan (kesengajaan) atau kelalaian.

\section{Kriteria dasar dan universal agar suatu Piercing the Corporate Veil secara hukum dapat dijatuhkan adalah sebagi berikut (Jono,} 2008:24):

1. Terjadinya penipuan;

2. Didapat suatu ketidakadilan;
3. Terjadi suatu penindasan (oppression);

4. Tidak memenuhi unsur hukum (illegal);

5. Dominasi pemegang saham berlebihan; dan

6. Perusahaan merupakan alter ego dari pemegang saham mayoritas.

Penerapan Piercing the

Corporate Veil ini pada hakekatnya bertujuan untuk melindungi kepentingan pemegang saham ataupun pihak ketiga yang dirugikan atas tindakan direksi yang sewenangwenang atau tidak layak yang dilakukan atas nama perseroan. Perbutan yang dilakukan terbit dari suatu transaksi dengan pihak ketiga maupun timbul dari perbuatan menyesatkan atau perbuatan melawan hukum.

Direksi dapat dikenakan Piercing the Corporate Veil apabila direksi melakukan hal-hal (Munir Fuady, 2010:22-25) sebagai berikut:

1. Direksi tidak melaksanakan fiduciary duty kepada perseroan. Direksi yang dengan sengaja atau lalai dalam menjalankan kewajiban fiduciary duty, tidak bertanggung jawab dan tidak beritikad baik dalam menjalankan pengurusan perseroan maka direksi tersebut bertanggung jawab secara pribadi sesuai dengan Pasal 1 angka 5 dan Pasal 97 ayat (3) UUPT. Gugatan terhadap Piercing the Corporate 
Veil ini dapat dilakukan oleh pihak ketiga yang merasa dirugikan dan/atau pemegang saham yang merasa dirugikan. Pemegang saham bertindak untuk dan atas nama perseroan. Pemegang saham yang diwakikan minimal $10 \%$ dari seluruh saham dan dengan suara yang sah;

2. Dokumen perhitungan tahunan tidak benar. Salah satu tugas direksi adalah menyediakan perhitungan laporan tahunan yang benar, bila terbukti laporan tahunan tersebut tidak benar maka direksi bersama dengan komisaris bertanggung jawab secara renteng berdasarkan prinsip Piercing the Corporate Veil sesuai denga ketentuan Pasal 69 ayat (3) UUPT. Pada Pasal 69 ayat (4) UUPT diberikan pembuktian terbalik oleh direksi dan komisaris; dan

3. Direksi bersalah dan menyebabkan perusahaan pailit:

a. Terdapat unsur kesalahan (kesengajaan) atau kelalaian dari direksi (dengan pembuktian biasa);

b. Untuk membayar utang dan ongkos-ongkos kepailitan, haruslah diambil terlebih dahulu dari aset-aset Perseroan. Apabila aset perseroan tidak memenuhi, barulah diambil dari aset direksi pribadi; dan

c. Diberlakukan pembuktian terbalik (omkering van bewijslast) bagi anggota direksi yang dapat membutikan bahwa kepailitan perseroan bukan karena kesalahan (kesengajaan) atau kelalaian.

Direksi dapat lepas dari tanggung jawab apabila direksi tersebut dapat membuktikan bahwa ia tidak bersalah sesuai dengan Pasal 104 dan Pasal 115 ayat (1) UUPT:

1. Permodalan yang tidak layak. Manakala modal perseroan tidak cukup layak untuk menunjang suatu kegiatan, maka kegiatan tersebut wajib untuk tidak dilakukan oleh direksi; dan

2. Perseroan beroperasi secara tidak layak. Apabila perseroan tidak beroperasi secara tidak layak sehingga merugikan pihak ketiga dan/atau pemegang saham, maka direksi bertanggung jawab sebagai pihak eksekutif perseroan berdasarkan doktrin fiduciary duty, kecuali apabila ia telah menjalankan tugasnya dengan benar sesuai dengan prinsipprinsip (business judgement rule).

\section{Pada Pasal 45 KUHD} ditentukan bahwa para pengurus tidak bertanggung jawab lebih daripada untuk menunaikan sebaik-baiknya tugas yang diberikan kepadanya; mereka tidak bertanggung jawab secara pribadi terhadap pihak ketiga atas perikatan perseroan. Apabila mereka melanggar suatu ketentuan dalam akta atau perubahan syaratsyaratnya yang diadakan kemudian, maka mereka bertanggung jawab masing-masing secara tanggung renteng untuk keseluruhannya atas 
kerugian-kerugian yang diderita oleh pihak ketiga karenanya.

Direksi juga dapat dijerat dengan Pasal 1365 dan 1366 KUHPerdata. Pada Pasal 1365 KUHPerdata disebutkan bahwa setiap perbuatan yang melanggar hukum dan membawa kerugian kepada orang lain, diwajibkan orang yang menimbulkan kerugian itu karena kesalahannya untuk menggantikan kerugian tersebut. Pada Pasal 1366 KUHPerdata juga ditegaskan bahwa setiap orang bertanggung jawab, bukan hanya atas kerugian yang disebabkan perbuatan-perbuatannya, melainkan juga atas kerugian yang disebabkan kelalaian atau kesembronoannya. Kedua pasal di atas merupakan dasar seseorang untuk dijerat berdasarkan prinsip perbuatan melawan hukum (onrechtmatige daad). Pada pasal tersebut ditegaskan mengenai seseorang yang melanggar hukum dalam hal ini UUPT dan ADRT PT yang bersangkutan wajib mengganti kerugian kepada pihak yang dirugikan karena kesembronoannya atau kelalaiannya.

Selain dapat dijerat dengan perkara perdata, kelalaian maupun kesalahan dari direksi tersebut dapat jua dijerat dengan ketentuan pidana melalui Pasal 398 dan Pasal 399 KUHP. Pada Pasal 398 KUHP dinyatakan bahwa seorang pengurus atau komisaris perseroan, maskapai andil Indonesia atau perkumpulan koperasi yang dinyatakan dalam keadaan pailit atau yang diperintahkan penyelesaian oleh pengadilan, diancam dengan pidana penjara paling lama satu tahun empat bulan:

1. Jika yang bersangkutan turut membantu atau mengizinkan untuk melakukan perbuatan-perbuatan yang bertentangan dengan anggaran dasar, sehingga oleh karena itu seluruh atau sebagian besar dari kerugian diderita oleh perseroan, maskapai, atau perkumpulan;

2. Jika yang bersangkutan dengan maksud untuk menangguhkan kepailitan atau penyelesaian perseroan, maskapai atau perkumpulan, turut membantu atau mengizinkan peminjaman uang dengan syarat-syarat yang memberatkan, padahal diketahuinya tak dapat dicegah keadaan pailit atau penyelesaiannya; dan

3. Jika yang bersangkutan dapat dipersalahkan tidak memenuhi kewajiban yang diterangkan dalam Pasal 6 ayat (1) Kitab UndangUndang Hukum Dagang dan Pasal 27 ayat (1) Ordonansi tentang Maskapai Andil Indonesia, atau 
bahwa buku-buku dan surat-surat yang memuat catatan-catatan dan tulisan-tulisan yang disimpan menurut pasal tadi, tidak dapat diperlihatkan dalam keadaan tak diubah.

Pasal 399 KUHP menambahkan bahwa seorang pengurus atau komisaris perseroan, maskapai andil Indonesia, atau perkumpulan koperasi yang dinyatakan dalam keadaan pailit atau yang penyelesaiannya diperintahkan oleh pengadilan, diancam dengan pidana penjara paling lama tujuh tahun, jika yang bersangkutan mengurangi secara curang hak-hak pemiutang dari perseroan, maskapai atau perkumpulan untuk:

1. Membuat pengeluaran yang tak ada, maupun tidak membukukan pendapatan atau menarik barang sesuatu dari budel;

2. Telah melijerkan (verureemden) barang sesuatu dengan cuma-cuma atau jelas di bawah harganya;

3. Dengan sesuatu cara menguntungkan salah seorang pemiutang di waktu kepailitan atau penyelesaian, ataupun pada saat di mana diketahuinya bahwa kepailitan atau penyelesaian tadi tak dapat dicegah;

4. Tidak memenuhi kewajiban mengadakan catatan menurut kitab Undang-Undang Hukum Dagang atau Pasal 27 ayat (1) Ordonansi tentang Maskapai Andil Indonesia, dan tentang menyimpan dan memperlihatkan buku-buku, suratsurat dan tulisan-tulisan menurut pasal-pasal itu.

\section{Pada Pasal 398 KUHP dapat} disimpulkan bahwa direksi maupun komisaris dapat dituntut pidana penjara selama satu tahun empat bulan (1 tahun 4 bulan) apabila direksi maupun komisaris menyebabkan kerugian bagi perseroan maupun pihak lain. Menurut Pasal 399 KUHP direksi maupun komisaris dapat dijerat dengan pidana penjara selama tujuh tahun apabila yang bersangkutan membuat kecurangan dengan mengurangi hak-hak para kreditor dan lalai dalam membuat pembukuan sebagaimana diwajibkan dalam anggaran dasar dan peraturan perundang-undangan.

\section{SIMPULAN}

Berdasarkan hasil pembahasan di atas, maka dapat disimpulkan bahwa direksi suatu PT dalam menjalankan pengurusan perseroan dilandasi oleh amanah yang diberikan oleh perseroan. Amanah ini dinamakan fiduciary duty, yang mengaharuskan direksi berhati-hati dan beritikad baik 
dalam

menjalankan

pengurusannya. Dalam kaitannya dengan fiduciary relations, tanggung jawab direksi dalam mengurus perseroan dapat diklasifikasikan adanya tanggung jawab direksi berdasarkan kepercayaan, amanah atau fiduciary duties, tanggung jawab direksi berdasarkan kecakapan, keahlian, kehati-hatian dan ketekunan atau duties of skill, dan tanggung jawab direksi berdasarkan undangundang atau statutory duties. Wewenang yang dimiliki direksi harus dijalankan sesuai dengan maksud dan tujuan perseroan yang terdapat dalam ADRT PT dan peraturan perundang-undangan. Apabila direksi bertindak melampaui batas kewenangannya, tindakan direksi tersebut menjadi tindakan ultra vires. Akibat dari ultra vires, tindakan tersebut batal demi hukum dan pihak yang dirugikan dapat meminta pertanggungjawaban direksi yang bersangkutan. Pelanggaran terhadap ketentuan tersebut mengakibatkan direksi harus bertanggungjawab secara pribadi. Tanggung jawab pribadi direksi dimungkinkan terjadi dalam hubungannya dengan prinsip Piercing the Corporate Veil dan Ultra Vires.

\section{SARAN}

1. Mengingat pengembangan prinsip PCV yang telah berkembang dapat menjerat direksi untuk bertanggungjawab secara pribadi, maka disarankan agar direksi menjalankan jabatannya dengan amanah dan moral yang tinggi agar tidak tergoda melakukan perbuatan melawan hukum untuk kepentingan pribadi dan golongannya.

2. Kepada para pemegang saham untuk memberikan pengawasan yang melekat karena terbukti banyak direksi yang bertindak di luar kewenangannya.

\section{DAFTAR PUSTAKA}

Ahmad Yani, Seri Hukum Bisnis Perseroan Terbatas, Rajawali Pers, Jakarta, 1999.

Chatamarrasjid Ais, Menyingkap Tabir Perseroan "Piercing 
the Corporate Veil" Kapita Selekta Hukum Perusahaan, PT. Citra Aditya Bakti, Bandung, 2000.

, Penerobosan Cadar Perseroan dan Soal-soal Aktual Hukum Perusahaan, Citra Aditya Bakti, Jakarta, 2004.

Friedman, Jack P., Dictionary of Business Term, Baron's Educational Series, Inc, New York, 1987.

Gunawan Widjaja, Tanggung Jawab Direksi atas Kepailitan, Cetakan Kedua, PT Raja Grafindo Persada, Jakarta, 2004.

, Risiko Hukum Pemilik, Direksi \& Komisaris PT, ForumSahabat, Cetakan Pertama, Jakarta, 2008.

Harahap, M. Yahya, Hukum Perseroan Terbatas, Sinar Grafika, Jakarta, 2009.

Jono, Hukum Kepailitan, Cetakan ketiga, Edisi Kesatu, Sinar Grafika, Jakarta, 2008.

Lipton, Phillip dan Herzberg, Abe, Understanding Company Law, Perth: The Law Book Company Limited, 1993.

Marwan, Kamus Hukum Dictionary of Law Complete Edition, Cetakan Kesatu, Reality Pubilser, Surabaya, 2009.
Munir Fuady, Doktrin-doktrin Modern Dalam Corporate Law dan Eksistensinya Dalam Hukum Indonesia, Cetakan Kedua, PT. Citra Aditya Bakti, Bandung, 2010.

Nindyo Pramono, Sertifikasi Saham PT Go Public dan Hukum Pasar Modal di Indonesia, Cetakan kedua, Edisi Revisi, Citra Aditya Bakti, Bandung, 2001.

Ridwan Khairandy, Perseroan Terbatas Doktrin, Peraturan Perundang-Undangan dan Yurisprudensi, Edisi Revisi, Total Media Yogyakarta, Yogyakarta, 2009.

Darmabrata,

Wahyono, "Implementasi Good Corporate Governance dalam Menyikapi Bentuk-Bentuk Penyimpangan Fiduciary Duty Direksi dan Komisaris Perseroan Terbatas", Jurnal Hukum Bisnis, Vol. 22, No. 6, 2003.

Kusumawardani, Shinta Ikayani, "Pengaturan Kewenangan, dan Tanggung Jawab Direksi dalam Perseroan Terbatas (Studi Perbandingan Indonesia dan Australia)", Jurnal Magister Hukum Udayana, Vol 2, No 1, 2013.

Nasution, Bismar, "Tanggung Jawab Direksi dan Komisaris Dalam Pengelolaan Perseroan Terbatas Bank", Makalah yang Disampaikan pada Seminar Sehari "Tanggung 
Jawab Pengurus Bank dalam Penegakan dan Penanganan Penyimpanan di Bidang Perbankan Menurut Undangundang Perseroan Terbatas dan Undang-undang Perbankan," diselenggarakan oleh Bank Indonesia dan Forum Komunikasi Direktur Kepatuhan Perbankan, Surabaya, tanggal 21 Februari 2008.

Syahdeni, Sutan Remi, "Tanggung Jawab Pribdai Direksi dan Komisaris," Jurnal Hukum Bisnis, Vol. 14, No. 7, 2001. Kitab Undang-Undang Hukum
Pidana.

Kitab Undang-Undang Hukum Perdata.

Kitab Undang-Undang Hukum Dagang.

Undang-Undang Nomor 1 Tahun 1995 tentang Perseroan
Terbatas (Lembaran Negara Republik Indoensia Tahun 1995 Nomor 13, Tambahan Lembaran Negara Republik Indonesia Nomor 3587).

Undang-Undang Nomor 40 Tahun 2007 tentang Perseroan Terbatas (Lembaran Negara Republik Indonesia Tahun 2007 Nomor 106, Tambahan Lembaran Negara Republik Indonesia Nomor 4756). 